\title{
Efficient degradation of ivermectin by newly isolated Aeromonas taiwanensis ZJB-18,044
}

\author{
Yuanshan Wang $\cdot$ Meihua Gong $\cdot$ Xianlin Wang $\cdot$ Xiaolun Peng • \\ Yuwei Wang · Jiahui Guan · Dongyuan Cheng • Chunyue Weng • \\ Yuguo Zheng
}

Received: 23 December 2019/Accepted: 5 September 2020/Published online: 16 September 2020

(C) Springer Nature B.V. 2020

\begin{abstract}
Ivermectin (IVM) is a widely used antiparasitic agent and acaricide. Despite its high efficiency against nematodes and arthropods, IVM may pose a threat to the environment due to its ecotoxcity. In this study, degradation of IVM by a newly isolated bacterium Aeromonas taiwanensis ZJB-18,044 was investigated. Strain ZJB-18,044 can completely degrade $50 \mathrm{mg} / \mathrm{L}$ IVM in $5 \mathrm{~d}$ with a biodegradation ability of $0.42 \mathrm{mg} / \mathrm{L} / \mathrm{h}$. Meanwhile, it exhibited high tolerance $(50 \mathrm{mg} / \mathrm{L})$ to doramectin, emamectin,
\end{abstract}

Electronic supplementary material The online version of this article (https://doi.org/10.1007/s10532-020-09909-8) contains supplementary material, which is available to authorized users.

Y. Wang $\cdot$ M. Gong $\cdot$ X. Wang $\cdot$ X. Peng .

Y. Wang · J. Guan · D. Cheng · C. Weng ·

Y. Zheng $(\bowtie)$

Key Laboratory of Bioorganic Synthesis of Zhejiang Province, College of Biotechnology and Bioengineering, Zhejiang University of Technology, No. 18, Chaowang Road, Hangzhou 310014, Zhejiang, People's Republic of China

e-mail: zhengyg@zjut.edu.cn

Y. Wang

e-mail: yuanshan@zjut.edu.cn

M. Gong

e-mail: gongmeihua12345@163.com

X. Wang

e-mail: 975418953@qq.com

X. Peng

e-mail: pengx11994@126.com rifampicin, and spiramycin. It can also efficiently degrade doramectin, emamectin, and spiramycin. The IVM degradation of strain ZJB-18,044 can be inhibited by erythromycin, azithromycin, spiramycin or rifampicin. However, supplement of carbonyl cyanide $m$-chlorophenylhydrazone, an uncoupler of oxidative phosphorylation, can partially recover the IVM degradation. Moreover, strain ZJB-18,044 cells can pump out excess IVM to maintain a low intracellular IVM concentration. Therefore, the IVM tolerance of strain ZJB-18,044 may be due to the regulation of the intracellular IVM concentration by the activated macrolide efflux pump(s). With the high IVM degradation efficiency, A. taiwanensis ZJB-18,044 may

Y. Wang

e-mail: 984320095@qq.com

J. Guan

e-mail: 3220016875@qq.com

D. Cheng

e-mail: 2371931520@qq.com

C. Weng

e-mail: cweng@zjut.edu.cn

Y. Wang $\cdot$ M. Gong $\cdot$ X. Wang $\cdot$ X. Peng ·

Y. Wang · J. Guan - D. Cheng - C. Weng · Y. Zheng

Engineering Research Center of Bioconversion and

Biopurification, Ministry of Education, Zhejiang

University of Technology, No. 18, Chaowang Road,

Hangzhou 310014, Zhejiang, People's Republic of China 
serve as a bioremediation agent for IVM and other macrolides in the environment.

Keywords Aeromonas taiwanensis .

Biodegradation · Efflux pump · Ivermectin · Tolerance

\begin{tabular}{|c|c|}
\hline \multicolumn{2}{|c|}{ Abbreviations } \\
\hline IVM & Ivermectin \\
\hline AVM & Avermectin \\
\hline $\begin{array}{l}\text { SARS- } \\
\text { CoV-2 }\end{array}$ & $\begin{array}{l}\text { Severe acute respiratory syndrome } \\
\text { coronavirus } 2\end{array}$ \\
\hline $\mathrm{CCCP}$ & $\begin{array}{l}\text { Carbonyl cyanide } m \text { - } \\
\text { chlorophenylhydrazone }\end{array}$ \\
\hline MSM & Mineral salts medium \\
\hline $\begin{array}{l}\text { LB } \\
\text { medium }\end{array}$ & Luria-Bertani medium \\
\hline $\begin{array}{l}\mathrm{MH} \\
\text { medium }\end{array}$ & Mueller-Hinton medium \\
\hline RNA & Ribonucleic acid \\
\hline NCBI & $\begin{array}{l}\text { The National Center for Biotechnology } \\
\text { Information }\end{array}$ \\
\hline HPLC & $\begin{array}{l}\text { High performance liquid } \\
\text { chromatography }\end{array}$ \\
\hline HPLC- & High performance liquid \\
\hline MS & chromatography mass spectrometry \\
\hline DO & Dissolved oxygen \\
\hline $\mathrm{OD}_{600}$ & Optical density at $600 \mathrm{~nm}$ \\
\hline MATE & Major facilitator superfamily \\
\hline RND & Resistance-nodulation-division \\
\hline ANOVA & Analysis of variance \\
\hline
\end{tabular}

\section{Introduction}

As a semi-synthetic insecticide, ivermectin (IVM) is a 22,23-dihydro derivative of avermectin (AVM) from Streptomyces avermitilis (Campbell et al. 1983; Chabala et al. 1980; Gonzalez Canga et al. 2009). IVM is widely used in agriculture, aquaculture, animal husbandry and pharmaceutical industries as an efficient broad-spectrum antiparasitic agent and acaricide

Y. Wang - M. Gong $\cdot$ X. Wang $\cdot$ X. Peng .

Y. Wang · J. Guan · D. Cheng · C. Weng · Y. Zheng

The National and Local Joint Engineering Research Center for Biomanufacturing of Chiral Chemicals, Zhejiang University of Technology, No. 18, Chaowang Road, Hangzhou 310014, Zhejiang, People's Republic of China against nematodes and arthropods (Gonzalez Canga et al. 2009; Poul 1988). In addition to the treatment and control of parasitic infections of domestic animals (Uhlir and Volf 1992), IVM is also approved to treat human onchocerciasis (Aziz et al. 1982), lymphatic flariasis (Fischer et al. 1997), streptocerciasis (Omura 2008), scabies and pediculosis (Yates et al. 2003). Moreover, IVM can reduce malaria transmission by killing Anopheles mosquitoes (Chaccour et al. 2013; Foy et al. 2011). Therapeutic effect of IVM on trichinosis (Basyoni and El-Sabaa 2013), leishmaniasis and trypanosomiasis (Abe and Bignell 2000), piroplasmosis (Batiha et al. 2019) were also reported. Furthermore, IVM was found to be capable of killing termites (Mo et al. 2005), body lice (Sangare et al. 2016) and Strongyloides stercoralis (Buonfrate et al. 2019). Currently, studies on antiviral (such as SARSCoV-2) (Caly et al. 2020; Yang et al. 2020), antituberculosis (Miró-Canturri et al. 2019) and anticancer effects of IVM are underway (Intuyod et al. 2019; Juarez et al. 2018; Omura and Crump 2014). These findings indicate the promising future of IVM in human health (Crump 2017).

Currently, increased attention has been paid to the toxicity and non-target effects of AVM and its derivatives such as IVM in terrestrial and aquatic environments (Lumaret et al. 2012; Sanderson et al. 2007). In contrast to low toxicity documented for mammals (Olsen and Snowman 1985), IVM has been shown to be extremely toxic to bees (Costa et al. 2014), silkworm and aquatic organisms, such as Brachydanio rerio (Hamilton-Buchanan), Daphnia magna straus, and Gambusia affinis (Davies et al. 1997; Katharios et al. 2002; Li 2010; Mladineo et al. 2006). Verdú et al. found that low doses of IVM can cause sensory and locomotor disorders in dung beetles (Ishikawa and Iwasa 2020; Verdú et al. 2015). It was also reported that IVM could pass through the bloodbrain barrier of the turtle, and cause serious consequences (Panayotova-Pencheva 2016). Therefore, the released IVM may be a threat to the aquatic environments.

Pharmacokinetic studies indicated that most of the IVM is excreted from feces and urine in their nonmetabolized form by mammalians (Sutherland and Campbell 1990). Residual IVM is mainly adsorbed into the soil. In addition to affect plant growth, IVM can also enter the plant through the plant roots, thereby endangering human health (Kumar et al. 
2005). Unlike most of other macrocyclic antibiotics (Masse et al. 2014), IVM is mainly degraded by photodegradation or microorganisms in terrestrial environments (Halley et al. 1993). However, adsorption of IVM to soil or feces significantly delayed its degradation (Davies et al. 1998; Floate et al. 2005; Wang et al. 2019; Wu et al. 2012). For example, over $70 \%$ of IVM remained after degradation for $70 \mathrm{~d}$ in the sediment of a simulated river way environment $(\mathrm{Wu}$ et al. 2012) and a half-life over $100 \mathrm{~d}$ of IVM was observed in marine sediment (Davies et al. 1998).

Currently, bioremediation has become one of the most promising tools to remove antibiotics and other pollutants in the environment (Alekseeva et al. 2011; He et al. 2014; Kumar et al. 2019; Pande et al. 2020). However, reports on biological degradation of IVM are rare (Hao 2009). In our previous research, a bacterium Stenotrophomonas maltophilia ZJB-14,120 was found to be capable of efficiently degrading abamectin, emamectin, erythromycin and spiramycin except IVM (Wang et al. 2015). Therefore, it is of interests to carry out researches on microbial degradation of IVM. Here we report the biological degradation of IVM by a macrolide-tolerant bacterium Aeromonas taiwanensis ZJB-18,044. A. taiwanensis ZJB-18,044 may serve as a biodegradation agent for IVM and other macrolides due to its high degradation efficiency.

\section{Materials and methods}

\section{Materials}

IVM (98\%) was provided by Hebei Meihe Pharmaceutical Co., Ltd. (China). Avermectin (97\%) and emamectin benzoate $(73 \%)$ were gifts from Zhejiang Qianjiang Biochemical Co., Ltd. (China). Erythromycin $(95 \%)$, spiramycin $(90 \%)$ and rifampicin (98\%) were purchased from J\&K Chemical Ltd. (China). Doramectin (98\%) and azithromycin dehydrate $(98 \%)$ were purchased from Aladdin Chemical Reagent Co., Ltd. (China). Carbonyl cyanide $m$ chlorophenylhydrazone (CCCP, reagent for qualitatively assaying the proton motive force-dependent pump) (Nagano and Nikaido 2009) was purchased from J\&K Chemical Ltd. (China). Acetonitrile, methanol, dichloromethane and other chemicals were of analytical grade and commercially available.
Microbial enrichment, isolation and IVM degradation assays were performed with the mineral salts medium (MSM, pH 7.0 -7.5) as described by Ali et al. (2010). The enrichment medium is MSM supplemented with $200 \mathrm{mg} / \mathrm{L}$ to $800 \mathrm{mg} / \mathrm{L}$ IVM. For cell cultivation, LB medium was used. Aeromonas taiwanensis was maintained on LB agar $(2.5 \% \mathrm{w} / \mathrm{v})$ plates. Antibiotic tolerance was assayed with Mueller-Hinton (MH) medium purchased from Aladdin Chemical Reagent Co., Ltd. (China). The media were autoclaved at $121{ }^{\circ} \mathrm{C}$ for $20 \mathrm{~min}$.

Soil samples were collected from surface layer $(2-10 \mathrm{~cm})$ soils in flower beds in campus of Zhejiang University of Technology and the ground of IVMproducing workshop in Hebei Meihe Pharmaceutical Co., Ltd. (China). Pig feces samples were provided by the Institute of Animal Husbandry and Veterinary Science, Zhejiang Academy of Agricultural Sciences. Soil samples were treated as previous research (Nagano and Nikaido 2009; Wang et al. 2015). Pig feces samples were fresh pig manure after feeding different doses of IVM.

Isolation and identification of IVM-degrading microorganisms

The IVM-degrading microorganisms were enriched by introducing $1 \mathrm{~g}$ of soil or fresh pig feces to $250 \mathrm{~mL}$ flasks with $50 \mathrm{~mL}$ of MSM containing $200 \mathrm{mg} / \mathrm{L}$ IVM, and then incubated at $30{ }^{\circ} \mathrm{C}$ and $150 \mathrm{rpm}$ on a rotary shaker in the dark for $2 \mathrm{~d}$. The resulting culture (3 mL) were sequentially transferred to fresh MSM with $400 \mathrm{mg} / \mathrm{L}, 600 \mathrm{mg} / \mathrm{L}$ and $800 \mathrm{mg} / \mathrm{L}$ IVM, and then incubated as described above. The enrichment culture was diluted and plated on LB agar plates containing $400 \mathrm{mg} / \mathrm{L}$ IVM, and then incubated at $30{ }^{\circ} \mathrm{C}$ in dark for $36 \mathrm{~h}$. After three cycles, the resulting colonies were picked up and introduced into $250 \mathrm{~mL}$ flasks with $50 \mathrm{~mL} \mathrm{LB}$ medium and incubated as aforementioned. Then $2 \mathrm{~mL}$ of bacterial suspension was transferred into MSM containing $50 \mathrm{mg} / \mathrm{L}$ IVM in $180 \mathrm{~mm} \times 18 \mathrm{~mm}$ test tube with silicone caps and subsequently incubated in dark at $30{ }^{\circ} \mathrm{C}, 150 \mathrm{rpm}$ for $60 \mathrm{~h}$. The reaction mixture was ultrasonicated and centrifuged at $10,000 \times g$ and $4{ }^{\circ} \mathrm{C}$ for $10 \mathrm{~min}$. Then the resulting supernatants were extracted with dichloromethane. The extracts were dehydrated with anhydrous $\mathrm{Na}_{2} \mathrm{SO}_{4}$, supplemented with acetonitrile to the original volume and then examined by HPLC analysis 
for IVM degradation ability. Strains capable of degrading over $65 \%$ of $50 \mathrm{mg} / \mathrm{L}$ IVM were primarily characterized with $16 \mathrm{~S}$ rRNA gene analysis. The $16 \mathrm{~S}$ rRNA gene of the strains was amplified using the universal primer set 27f (5'-AGAGTTTGATCMTGGCTCAG-3') and 1492r (5'-TACGGYTACCTTGTTACGACTT-3') (Lane 1991), and sequenced by TSINGKE Biotech (Hangzhou) Co., Ltd (China). Homology analysis was performed with 16S rRNA sequences in NCBI by Blast software. The multiple sequence alignment was analyzed by BioXM 2.6 (Thompson et al. 1994). With the highest degradation ability, strain ZJB-18,044 was selected for further study. Morphological characterization of strain ZJB-18,044 was performed after $24 \mathrm{~h}$ incubation on LB agar plate. Cell morphology was observed with Olympus CH20 light microscope (Olympus Microsystems, Japan). Physiological and biochemical characterization were carried out with a GEN III microplate and analyzed by a MicroStation (Biolog, USA). A phylogenetic tree based on the 16S rRNA gene sequences of strain ZJB-18,044 and closely related strains was constructed by the Neighbor-Joining method using MEGA7. The evolutionary distances were calculated with the Maximum Composite Likelihood method.

\section{IVM biodegradation experiments}

Unless otherwise mentioned, the biodegradation of IVM by strain ZJB-18,044 was carried out in 180 $\mathrm{mm} \times 18 \mathrm{~mm}$ test tubes with silicone caps. To evaluate the effect of growing medium on IVM degradation, strain ZJB-18,044 was grown in $5 \mathrm{~mL}$ LB medium or $5 \mathrm{~mL} \mathrm{MSM} \mathrm{containing} 20 \mathrm{mg} / \mathrm{L}$ IVM for $12 \mathrm{~h}$ at $30{ }^{\circ} \mathrm{C}$ and $150 \mathrm{rpm}$. Then $2 \mathrm{~mL}$ of the resulting LB culture and MSM culture were introduced into $3 \mathrm{~mL} \mathrm{MSM}$ and $3 \mathrm{~mL} \mathrm{LB}$ medium (all supplemented with IVM to final concentration of $50 \mathrm{mg} / \mathrm{L}$ ) respectively, and then cultivatetd for $72 \mathrm{~h}$ in the dark at $30{ }^{\circ} \mathrm{C}$ and $150 \mathrm{rpm}$. The culture broth was ultrasonicated and extracted as described above, then analyzed with HPLC.

Resting cells were prepared from the LB culture by centrifugation at $10,000 \times g$ and $4{ }^{\circ} \mathrm{C}$ for $10 \mathrm{~min}$. The resulting cells were washed once with an equal volume of sterile $0.2 \mathrm{M}$ phosphate buffer ( $\mathrm{pH} 7.5$ ), and then resuspended in the same buffer. IVM tolerance and utilization of growing cells was carried out by introducing $2 \mathrm{~mL}$ LB culture into $3 \mathrm{~mL}$ MSM supplemented with IVM to final concentration of $10 \mathrm{mg} / \mathrm{L}, 30 \mathrm{mg} / \mathrm{L}, 50 \mathrm{mg} / \mathrm{L}, 80 \mathrm{mg} / \mathrm{L}, 100 \mathrm{mg} / \mathrm{L}$, $150 \mathrm{mg} / \mathrm{L}$ and $200 \mathrm{mg} / \mathrm{L}$ IVM. As for IVM tolerance and utilization of the resting cells, $2 \mathrm{~mL}$ resting cells suspension was used.

Degradation of IVM by strain ZJB-18,044 was further examined in $5 \mathrm{~L}$ fermenter $(\mathrm{BIOTECH}$, China). LB culture of strain ZJB-18,044 cultivated in $500 \mathrm{~mL}$ flasks containing $100 \mathrm{~mL} \mathrm{LB}$ at $30^{\circ} \mathrm{C}$ and $150 \mathrm{rpm}$ for $12 \mathrm{~h}$ were pooled and introduced into the $5 \mathrm{~L}$ fermenter (with 2.7 L MSM supplemented with IVM to final concentration of $50 \mathrm{mg} / \mathrm{L}$ or $100 \mathrm{mg} / \mathrm{L}$ ) at a $10 \%(\mathrm{~V} / \mathrm{V})$ inoculation size. The initial incubation conditions were $30{ }^{\circ} \mathrm{C}, 200 \mathrm{rpm}$, aeration rate $2.0 \mathrm{~L} /$ (L min), and $\mathrm{pH}$ 7.5. The dissolved oxygen (DO) was maintained above $30 \%$ throughout the fermentation and samples were withdrawn every $12 \mathrm{~h}$.

The utilization and tolerance of strain ZJB-18,044 towards avermectin (16-membered-ring macrolide), doramectin (16-membered-ring macrolide), emamectin(16-membered-ring macrolide), erythromycin (14membered-ring macrolide), azithromycin (15-membered-ring macrolide), spiramycin (16-memberedring macrolide) or rifampicin (ansa macrolide) were investigated by incubating the strain in MSM or MH medium separately containing the macrolides in the dark at $30{ }^{\circ} \mathrm{C}$ and $150 \mathrm{rpm}$ for $72 \mathrm{~h}$. Then the biomass and macrolides concentrations were determined.

To determine whether the aforementioned macrolides can induce the IVM degradation, IVM (final concentration $50 \mathrm{mg} / \mathrm{L}$ ) was introduced into $48 \mathrm{~h}$ cultures of strain ZJB-18,044 in LB or LB separately supplemented with the macrolides, and then further incubated for $72 \mathrm{~h}$.

The IVM degradation metabolites of strain ZJB18,044 was determined by HPLC-MS analysis of the IVM degradation products of growing cells. The $4 \mathrm{~h}$ to $32 \mathrm{~h}$ culture broth of strain ZJB-18,044 in MSM with $50 \mathrm{mg} / \mathrm{L}$ IVM was ultrasonicated and centrifuged at $10,000 \times g$ and $4{ }^{\circ} \mathrm{C}$ for $10 \mathrm{~min}$. Then the resulting supernatants were extracted with dichloromethane for IVM and corresponding metabolites. The HPLC-MS was performed with a Thermo Scientific LTQ XL mass analyzer attached to a Dionex UltiMate 3000 system equipped with a Hypersil gold C18 column $(100 \mathrm{~mm} \times 2.1 \mathrm{~mm} \times 3 \mu \mathrm{m})$. Sample $(20 \mu \mathrm{L})$ was loaded. The elution method is $8 \mathrm{~min} 2 \%-100 \%$ acetonitrile, $5 \min 100 \%-2 \%$ acetonitrile, $2 \min 2 \%$ 
acetonitrile in total $15 \mathrm{~min}$. The flow rate of the mobile phase was $0.6 \mathrm{~mL} / \mathrm{min}$.

The IVM-tolerant mechanism of strain ZJB-18,044 was investigated in $3 \mathrm{~L}$ MSM medium supplemented with $50 \mathrm{mg} / \mathrm{L}, 100 \mathrm{mg} / \mathrm{L}$ and $200 \mathrm{mg} / \mathrm{L}$ IVM within $5 \mathrm{~L}$ fermenter and incubated as described above. Samples were withdrawn at 0, 6, 12, 24, 36, 48, 60, 72, 96 and $120 \mathrm{~h}$, and then centrifuged at $10,000 \times g$ and $4{ }^{\circ} \mathrm{C}$ for $10 \mathrm{~min}$. The harvested cells were resuspended and disrupted for determination of intracellular IVM as previous research (Wang et al. 2015).

Analytical methods

Biomass was assayed by measuring the optical density at $600 \mathrm{~nm}\left(\mathrm{OD}_{600}\right)$. Concentration of AVM and its derivatives (IVM, doramectin and emamectin) and other macrolide antibiotics was determined by Agilent HPLC-1260 Infinity (Agilent, USA) using a Unitary C18 column $(250 \mathrm{~mm} \times 4.6 \mathrm{~mm} \times 5 \mu \mathrm{m}) \quad($ Acchrom, China) as previous research (Wang et al. 2015). Briefly, AVM, IVM, doramectin and emamectin were monitored at $245 \mathrm{~nm}$ with acetonitrile-water (90:10, v/v) at $2.0 \mathrm{~mL} / \mathrm{min}$. Other macrolides were monitored at $215 \mathrm{~nm}$ with $\mathrm{K}_{2} \mathrm{HPO}_{4}$ buffer $(0.05 \mathrm{M}$, $\mathrm{pH} 8.2)$-acetonitrile $(50: 50, \mathrm{~V} / \mathrm{V})$ at $1.0 \mathrm{~mL} / \mathrm{min}$. The data was analyzed with analysis of variance (ANOVA) statistics with SPSS (IBM, USA).

\section{Results}

Isolation and identification of IVM-degrading microorganisms

Among 157 different single colonies obtained from enrichment and streaking, 12 bacterial strains capable of efficiently degrading IVM (over 65\% degradation) were isolated and primarily identified based on $16 \mathrm{~S}$ rRNA gene analysis (Table 1). Strain ZJB-18,044, a bacterium with the highest IVM degradation (75.3\%), was isolated from a pig feces sample. The strain was a Gram negative, motile and rod-shaped bacterium. The morphologies of the colonies were round, raised, pale yellow and translucent on LB agar plates. The physical and biochemical characteristics of strain ZJB-18,044 (Table 2) suggested that the isolate was Aeromonas caviae (identity 0.52). Homology analysis of the partial nucleotide sequence of $16 \mathrm{~S}$ rRNA gene
(1413 bp, GenBank accession number: MK359642) showed that strain ZJB-18,044 had similarity above 99\% with Aeromonas taiwanensis strain A2-50 (GenBank accession number: NR116585, 99.72\%) and Aeromonas caviae strain W20 (GenBank accession number: KC840846, 99.65\%). The phylogenetic tree constructed based on the 16S rRNA gene sequences of strain ZJB-18,044 and closely related strains is shown in Fig. 1. According to the phylogenetic tree, strain ZJB-18,044 is closest to Aeromonas taiwanensis strain A2-50, which is different with physiological data from the Biolog system. However, there is no data of Aeromonas taiwanensis in the Database of Biolog system (https://www.biolog.com/ wp-content/uploads/2020/04/00A-005rC-Biolog-

Database-Book.pdf). Therefore, strain ZJB-18,044 was identified as Aeromonas taiwanensis.

Effects of temperature $\left(20-35{ }^{\circ} \mathrm{C}\right)$ and initial $\mathrm{pH}$ ( $\mathrm{pH} 4-10$ ) on IVM degradation by A. taiwanensis strain ZJB-18,044 were investigated. As depicted in Fig. 2, from 28 to $35^{\circ} \mathrm{C}$, IVM degradation reached above $65 \%$. And as depicted in Fig. 3, from $\mathrm{pH} 7$ to 9 , IVM degradation reached above $69 \%$. Therefore, the optimum temperature and initial $\mathrm{pH}$ were $28^{\circ} \mathrm{C}$ and 7.5 , respectively (Figs. 2 and 3). The results showed that ZJB-18,044 could degrade IVM in a temperature range of $28{ }^{\circ} \mathrm{C}$ to $35^{\circ} \mathrm{C}$ and an alkaline environment.

Degradation and tolerance towards IVM of $\boldsymbol{A}$.

taiwanensis strain ZJB-18,044

Effects of IVM concentrations on the growth and IVM degradation of strain ZJB-18,044 were investigated by incubating the growing cells (Fig. 4a) and resting cells (Fig. 4b) in MSM supplemented with $10-200 \mathrm{mg} / \mathrm{L}$ IVM for $3 \mathrm{~d}$. The data showed that the strain could grow under all tested IVM concentrations. The biomass increased from $10 \mathrm{mg} / \mathrm{L}$ IVM to $50 \mathrm{mg} / \mathrm{L}$ IVM, and then dropped at higher IVM concentrations. No significant changes in the biomass were observed in the resting cell treatments. As for IVM degradation, the IVM degradation of the resting cells (the highest IVM degradation $(11.3 \mathrm{mg} / \mathrm{L})$ was obtained under $100 \mathrm{mg} / \mathrm{L}$ IVM) was much lower than that of the growing cells (over $35 \mathrm{mg} / \mathrm{L}$ IVM was degraded under 50-200 mg/L IVM) (Fig. 4). This may due to the requirement of coenzymes for the biodegradation, 
Table 1 Microorganisms with IVM degradation ability and their IVM degradation rate

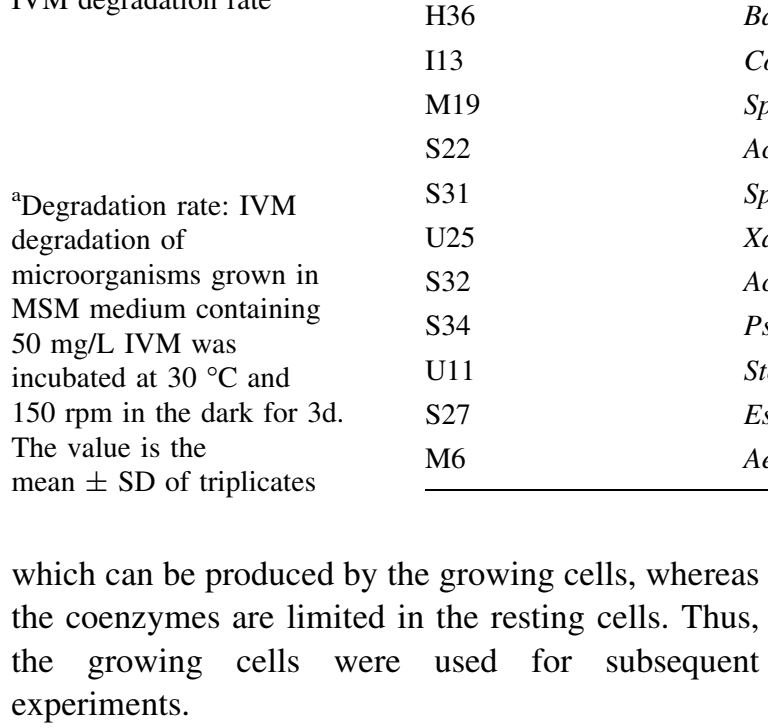

In the treatments of pre-culturing in $50 \mathrm{mg} / \mathrm{L} \mathrm{IVM}$ containing $\mathrm{LB}$ and MSM, the $\mathrm{OD}_{600}$ was 1.28 and 1.02 , respectively. Regardless of the difference in biomass, there was no significant difference in IVM degradation in the two treatments $(75.3 \%$ in the treatment of IVM containing LB and $75.2 \%$ in the treatment of IVM containing MSM, respectively).

Large scale degradation of IVM by A. taiwanensis strain ZJB-18,044 was further investigated in a $5 \mathrm{~L}$ fermenter (Fig. 5). Strain ZJB-18,044 can completely degrade $50 \mathrm{mg} / \mathrm{L}$ IVM in $5 \mathrm{~d}$ with $\mathrm{OD}_{600}$ value 1.93 (Fig. 5a). The strain also can degrade $98.92 \%$ of $100 \mathrm{mg} / \mathrm{L}$ IVM in $10 \mathrm{~d}$ with $\mathrm{OD}_{600}$ value 2.61 (Fig. 5b).

Degradation of other macrolides by A. taiwanensis strain ZJB-18,044

Among the tested macrolides, strain ZJB-18,044 can grow well in MSM containing emamectin, doramectin or spiramycin. It grew poorly in MSM containing AVM and could not grow in MSM containing azithromycin, erythromycin or rifampicin. This was consistent with its degradation towards all tested macrolides (Fig. 6). Furthermore, it could grow in $\mathrm{MH}$ medium supplemented with the tested macrolides except for azithromycin and erythromycin (Table 3).
Effect of other macrolides on IVM degradation by A. taiwanensis strain ZJB-18,044

Effect of other tested macrolides on IVM degradation by the strain was investigated by supplementing IVM (final concentration of $50 \mathrm{mg} / \mathrm{L}$ ) to the $48 \mathrm{~h}$ culture grown in LB or LB separately containing the antibiotics described. As depicted in Fig. 6, strain ZJB18,044 almost completely degraded $50 \mathrm{mg} / \mathrm{L}$ IVM in 5 $\mathrm{d}$ in LB medium and LB medium pre-cultured with IVM, AVM, doramectin and emamectin. No significant IVM degradation was observed when the strain was pre-cultured in LB medium with erythromycin, azithromycin, spiramycin and rifampicin (Fig. 7). However, the IVM degradation in these treatments can be recovered with the addition of CCCP (Fig. 7).

Identification of IVM degradation metabolites

HPLC-MS analysis revealed that there were two main metabolites with retention times at 3.96 and $4.82 \mathrm{~min}$ among the IVM degradation metabolites. By comparison, two IVM degradation metabolites can be presumed from the mass spectrum corresponding to the retention time at $3.96 \mathrm{~min}(\mathrm{~m} / z$ 750.0, Metabolite A) and $4.82 \mathrm{~min}(\mathrm{~m} / \mathrm{z}, 150.0$, Metabolite B) (Fig. S1). The IVM degradation metabolites of strain ZJB18,044 were proposed in Fig. S2. 
Table 2 Physiological and biochemical characteristics of strain ZJB18044
+ positive, - negative, $\mathrm{B}$ borderline

\begin{tabular}{|c|c|c|c|}
\hline Characteristic & Results & Characteristic & Results \\
\hline Lincomycin & + & Gelatin & B \\
\hline Guanidine $\mathrm{HCl}$ & + & Nalidixic acid & - \\
\hline Dextrin & + & Glycyl-L-prolin & + \\
\hline D-Maltose & + & L-Alanine & + \\
\hline D-Trehalose & + & $1 \% \mathrm{NaCl}$ & + \\
\hline D-Cellobiose & + & L-Glutamic acid & + \\
\hline Gentiobiose & - & L-Histidine & + \\
\hline Sucrose & + & L-Pyroglutamic acid & - \\
\hline D-Turanose & - & Lithium chloride & + \\
\hline Stachyose & - & Pectin & - \\
\hline D-Raffinose & - & D-Galacturonic acid & - \\
\hline$\alpha$-D-Lactose & - & L-Galactonic acid lactone & - \\
\hline D-Melibiose & - & D-Gluconic acid & + \\
\hline$\beta$-Methyl-D-glucoside & + & Troleandomycin & + \\
\hline D-Salicin & + & Glucuronamide & - \\
\hline$N$-Acetyl-D-glucosamine & + & Mucic acid & - \\
\hline $\mathrm{N}$-Acetyl-D-galactosamine & - & Quinic acid & - \\
\hline$N$-Acetyl neuraminic acid & - & D-Saccharica acid & - \\
\hline$\alpha$-D-Glucose & - & $p$-Hydroxy-phenylacetic acid & - \\
\hline D-Mannose & - & Methyl pyruvate & - \\
\hline D-Fructose & - & D-Lactic acid methyl ester & - \\
\hline D-Galactose & + & L-Lactic acid & + \\
\hline 3-Methyl glucose & - & Citric acid & - \\
\hline D-Fucose & - & $\alpha$-Keto-glutaric acid & - \\
\hline $1 \%$ Sodium lactate & + & D-Malic acid & - \\
\hline L-Rhamnose & - & L-Malic acid & + \\
\hline Inosine & + & Bromo-succinic acid & + \\
\hline D-Sorbitol & - & Tween 40 & - \\
\hline D-Mannitol & - & $\gamma$-Amino-butryric acid & - \\
\hline D-Arabitol & - & $\alpha$-Hydroxy-butyric acid & + \\
\hline myo-Inositol & - & $\beta$-Hydroxy-D,L butyric acid & - \\
\hline Glycerol & + & $\alpha$-Keto-butyric acid & + \\
\hline D-Glucose-6- $\mathrm{PO}_{4}$ & - & Acetoacetic acid & + \\
\hline D-Fructose-6- $\mathrm{PO}_{4}$ & + & Propionic acid & + \\
\hline D-Aspartic acid & - & Sodium bromate & - \\
\hline Minocycline & - & Rifamycin SV & + \\
\hline D-Serine & + & Formic Acid & + \\
\hline
\end{tabular}

IVM degradation process included 3 steps. In Step one $(0-6 \mathrm{~h}), \mathrm{Ce}$ in all treatments decreased rapidly with a simultaneously increase in Ci (Fig. 8a-d). In Step two (6-12 h), Ci in treatment A, B and C all decreased while $\mathrm{Ce}$ increased, which may be due to the expel out of IVM by the active efflux (Fig. 8a-c). As to treatment $\mathrm{D}, \mathrm{Ce}$ and $\mathrm{Ci}$ only changed slightly 


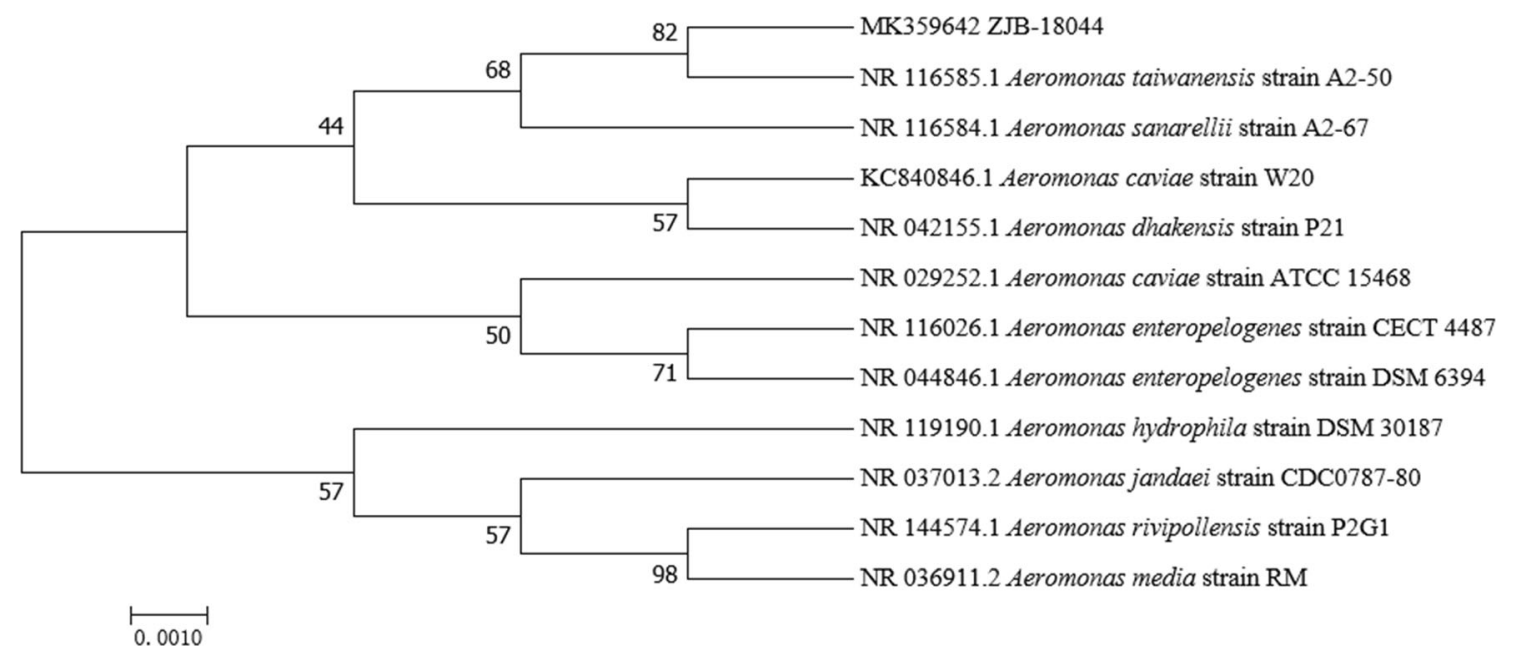

Fig. 1 Phylogenetic tree constructed with the Neighbor-Joining method based on the 16S rRNA gene sequences of strain ZJB18,044 and closely related strains. Numbers presented in fornt of the strains are GenBank accession numbers of the sequences.

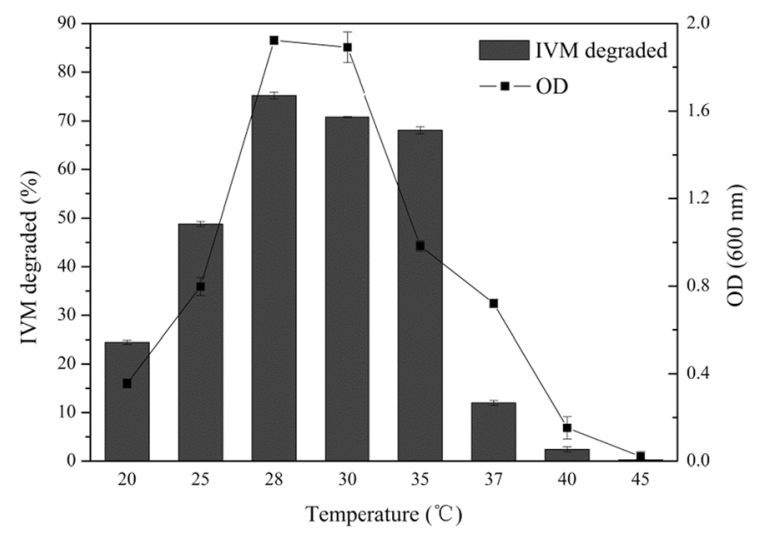

Fig. 2 Effect of temperature on growth and IVM degradation of A. taiwanensis strain ZJB-18,044 grown in MSM medium. The strain was incubated at initial $\mathrm{pH} 7.0$ and $150 \mathrm{rpm}$ in the dark for 3 d. Error bars: mean \pm SD of triplicates

(Fig. 8d), which may result from the inactivation of the active efflux by CCCP which caused de-energization of the cytoplasmic membrane. The total IVM concentrations in all treatments remained stable in these two steps. In the last step (12 h-120 h), no significant changes in $\mathrm{Ci}$ in all treatments was observed (Fig. 8a-d). However, Ci in treatment D was much higher than those in treatment $\mathrm{A}, \mathrm{B}$ and $\mathrm{C}$. Except for treatment D, Ce and total IVM in other treatments all decreased.
Evolutionary distances were computed with Maximum Composite Likelihood method. The scale bar represents 0.001 substitutions per nucleotide position. Evolutionary analysis was conducted with MEGA7

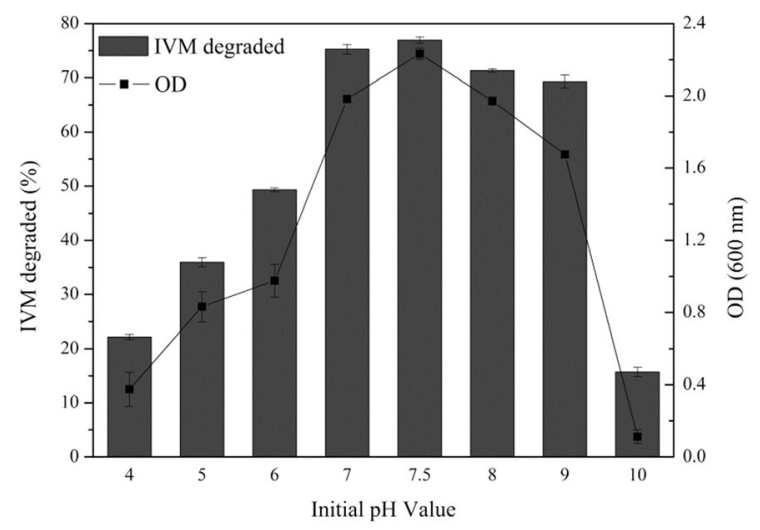

Fig. 3 Effect of initial $\mathrm{pH}$ value on growth and IVM degradation of A. taiwanensis strain ZJB-18,044 grown in MSM medium. The strain was incubated at $28^{\circ} \mathrm{C}$ and $150 \mathrm{rpm}$ in the dark for $3 \mathrm{~d}$. Error bars: mean $\pm \mathrm{SD}$ of triplicates

\section{Discussion}

As a potent and broad-spectrum antiparasitic agen$\mathrm{t}$ and acaricide, IVM has been widely applied in various fields such as aquaculture and husbandry. However, in the husbandry most of the administered IVM was released in feces or urine to environment with its unmetabolized form. Either in water or firmly bound to the soil, IVM has a long elimination half-life (Floate et al. 2005; Wang et al. 2019; Wu et al. 2012). IVM has adverse effects not only on non-target 

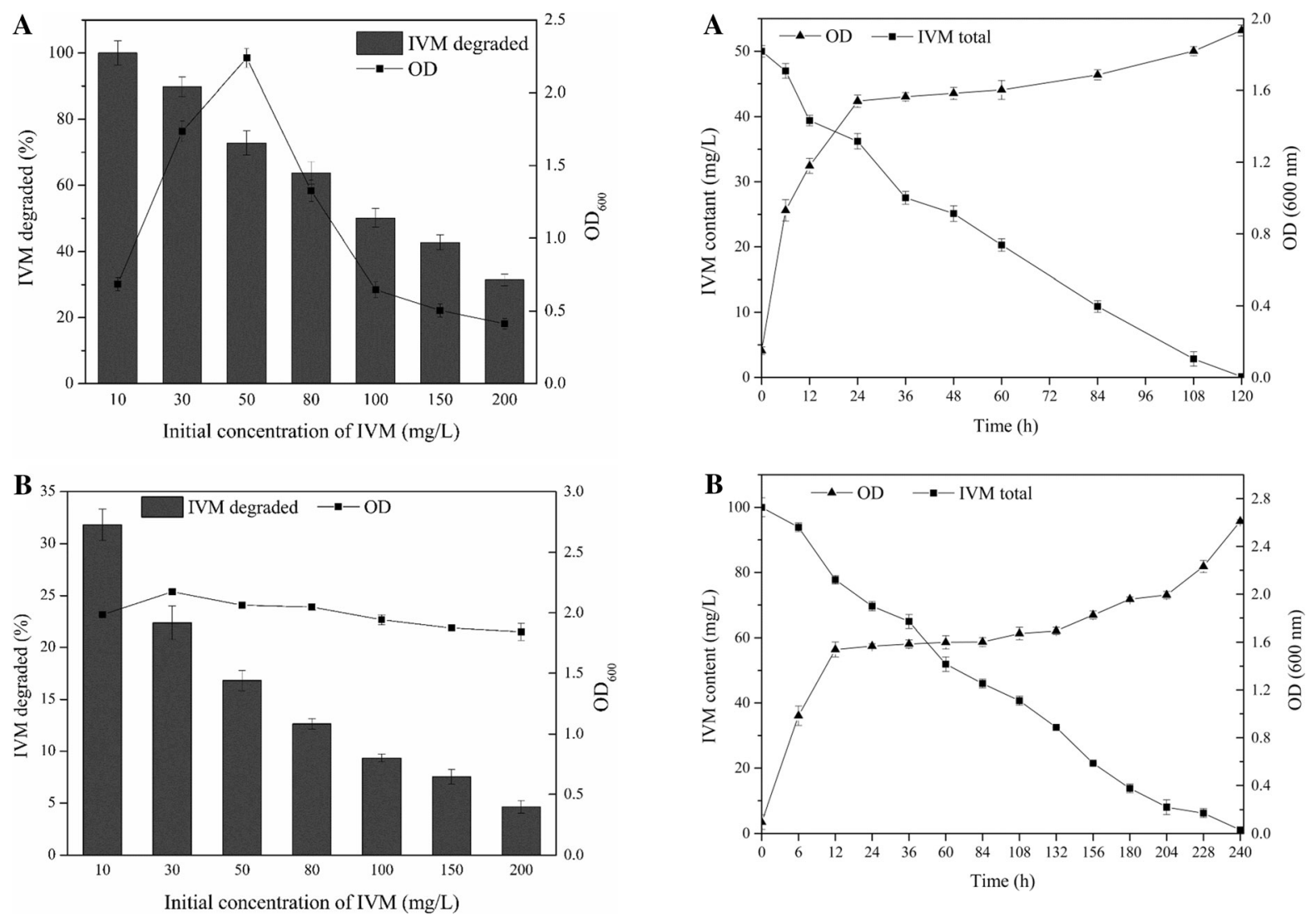

Fig. 4 Effect of IVM concentrations on growth and IVM degradation of A. taiwanensis strain ZJB-18,044 grown in MSM medium with growing cells (a) and resting cells (b). The strain was incubated at $28^{\circ} \mathrm{C}$ and $150 \mathrm{rpm}$ in the dark for $3 \mathrm{~d}$. Error bars: mean $\pm \mathrm{SD}$ of triplicates

organisms such as terrestrial microbes and aquatic organisms, but also on other organisms through the food chain. That is, the releasing IVM may cause ecological problems (Floate et al. 2005; Lumaret and Errouissi 2002; Wang et al. 2019). Therefore, investigation on bio-degradation of IVM is of great importance.

In the present research, A. taiwanensis strain ZJB18,044 , a bacterium with potent IVM degradation, was isolated and characterized. The data revealed that this strain is a macrolides tolerant bacterium and capable of degrading some macrolides such as IVM, doramectin and emamectin. The strain can efficiently degrade IVM at a temperature from 28 to $35{ }^{\circ} \mathrm{C}$ and initial $\mathrm{pH}$ (pH 7-9). Furthermore, growing cells of strain ZJB-18,044 exhibited more potent IVM degradation ability than resting cells.

Fig. 5 Degradation of $50 \mathrm{mg} / \mathrm{L}$ (a) and $100 \mathrm{mg} / \mathrm{L}$ (b) IVM by growing cells of $A$. taiwanensis strain ZJB-18,044 in $5 \mathrm{~L}$ fermenter. The reaction mixture was incubated at $30{ }^{\circ} \mathrm{C}$ and $150 \mathrm{rpm}$ for $5 \mathrm{~d}$ or $10 \mathrm{~d}$ in MSM medium. Error bars: mean $\pm \mathrm{SD}$ of triplicates

Up to date, there is only one available report on microbial degradation of IVM (Hao 2009). Hao isolated a bacterial strain Pseudomonas sp. strain K1 from pig feces, which can degrade $15.7 \%$ of $40 \mathrm{mg} / \mathrm{L}$ IVM in $30 \mathrm{~d}$ at $30{ }^{\circ} \mathrm{C}$ and $150 \mathrm{rpm}$. Its average IVM degradation rate $(8.72 \mu \mathrm{g} / \mathrm{L} / \mathrm{h}$ under $40 \mathrm{mg} / \mathrm{L} \mathrm{IVM})$ is 47.7 times lower than that of the strain ZJB-18,044 $(0.416 \mathrm{mg} / \mathrm{L} / \mathrm{h}$ under $50 \mathrm{mg} / \mathrm{L}$ IVM). Thus, strain ZJB-18,044 can serve as an efficient IVM degrading agent.

Strain ZJB-18,044 can efficiently degrade IVM but not AVM. This is contrary to Stenotrophomonas maltophilia ZJB-14,120 (Wang et al. 2015) and Bacillus cereus strain AVM1 (Li 2010), which can degrade AVM but not IVM. Among doramectin, emamectin and spiramycin, strain ZJB-18,044 displayed the highest degradation towards emamectin. Except S. maltophilia ZJB-14,120, reports on 
microbial degradation of emamectin are rare (Wang et al. 2015). As to spiramycin, it is reported that Aspergillus sclerotiorum and Microcystis aeruginosa can degrade spiramycin (Liu et al. 2012a, b). Due to the lack of researches on doramectin, emamectin or spiramycin degradation by $A$. taiwanensis, it is important to elucidate macrolides-degrading enzymes/genes in A. taiwanensis strain ZJB-18,044.

HPLC-MS analysis of the IVM degradation products revealed that there are two metabolites (Fig. S1).



Fig. 6 Degradation of macrolides by growing cells of $A$. taiwanensis strain ZJB-18,044. The macrolides were separately introduced into the growing cell suspension to $50 \mathrm{mg} / \mathrm{L}$, incubated at $28{ }^{\circ} \mathrm{C}$ and $150 \mathrm{rpm}$ in the dark for $3 \mathrm{~d}$. Error bars: mean $\pm \mathrm{SD}$ of triplicates
A primary biodegradation pathway for IVM of $A$. taiwanensis strain ZJB-18,044 was proposed (Fig. S2). As depicted in Fig. S2, the IVM biodegradation begins with the breakage of the $\mathrm{C}-\mathrm{O}$ bond between $\mathrm{C} 4$ and O11, and forms metabolite A (the ion at $\mathrm{m} / \mathrm{z}, 750.0$ ) and metabolite $\mathrm{B}(\mathrm{m} / \mathrm{z}, 150.0)$. Up to date, the information on the mechanism of microbial degradation of IVM is

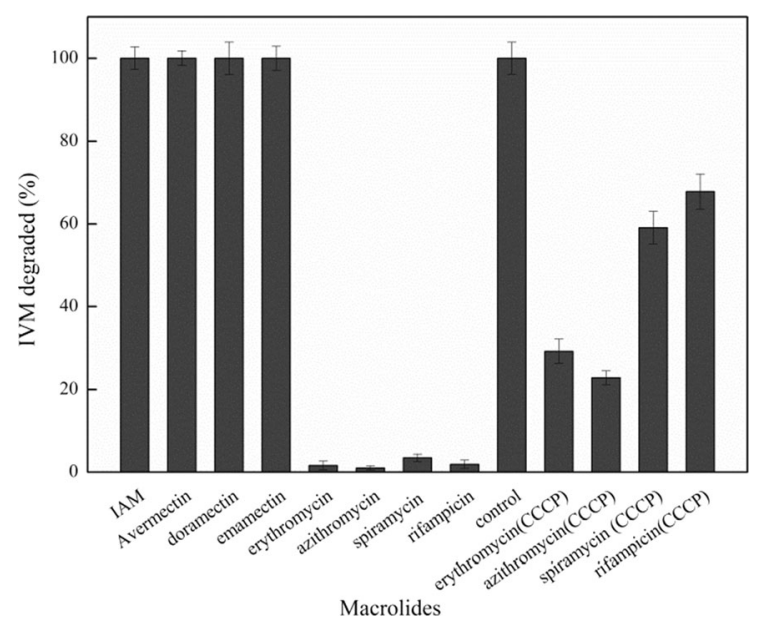

Fig. 7 Degradation of IVM by growing cells of A. taiwanensis strain ZJB-18,044 grown in LB medium supplemented with IVM, avermectin, doramectin, emamectin, erythromycin, azithromycin, spiramycin and rifampicin. The last 4 bars stand for the reaction mixture additionally supplemented with $8 \mathrm{mg} / \mathrm{L}$ CCCP. Cells cultivated in pure LB medium were set as controls. The reaction mixture containing $50 \mathrm{mg} / \mathrm{L}$ IVM was incubated at $28^{\circ} \mathrm{C}$ and $150 \mathrm{rpm}$ in the dark for $5 \mathrm{~d}$. Error bars: mean $\pm \mathrm{SD}$ of triplicates

Table 3 Growth of A. taiwanensis Strain ZJB-18,044 in MSM and MH with different kinds of macrolides

\begin{tabular}{llr}
\hline Substrates & $\mathrm{MSM}^{\mathrm{a}}\left(\mathrm{OD}_{600 \mathrm{~nm}}\right)$ & $\mathrm{MH}^{\mathrm{b}}\left(\mathrm{OD}_{600 \mathrm{~nm}}\right)$ \\
\hline Avermectin & $0.0812 \pm 0.0015$ & $1.2423 \pm 0.0312^{*}$ \\
Doramectin & $0.7285 \pm 0.0032^{* *}$ & $1.0412 \pm 0.0507$ \\
Emamectin benzoate & $0.7418 \pm 0.0011^{* *}$ & $1.1466 \pm 0.0231^{*}$ \\
Erythromycin & $0.0429 \pm 0.0015$ & $0.0483 \pm 0.0042$ \\
Azithromycin & $0.0373 \pm 0.0047$ & $0.0557 \pm 0.0095$ \\
Spiramycin & $0.4973 \pm 0.0011^{*}$ & $1.1133 \pm 0.0523$ \\
Rifampcin & $0.0302 \pm 0.0018$ & $1.0289 \pm 0.0132^{*}$ \\
Control & $0.0461 \pm 0.0054$ & $0.0492 \pm 0.0016$ \\
\hline
\end{tabular}

${ }^{\mathrm{a}} 50 \mathrm{mg} / \mathrm{L}$ different macrolides were respectively added into MSM as sole carbon source, incubated at $30{ }^{\circ} \mathrm{C}$ and $150 \mathrm{rpm}$ in the dark for $3 \mathrm{~d}$. The value is the mean $\pm \mathrm{SD}$ of three replicates

${ }^{\mathrm{b}} 100 \mathrm{mg} / \mathrm{L}$ different macrolides were respectively added into $\mathrm{MH}$ as antibiotic stress, incubated at $30{ }^{\circ} \mathrm{C}$ and $150 \mathrm{rpm}$ in the dark for $3 \mathrm{~d}$. The value is the mean $\pm \mathrm{SD}$ of triplicates

*Significant, ** very significant 

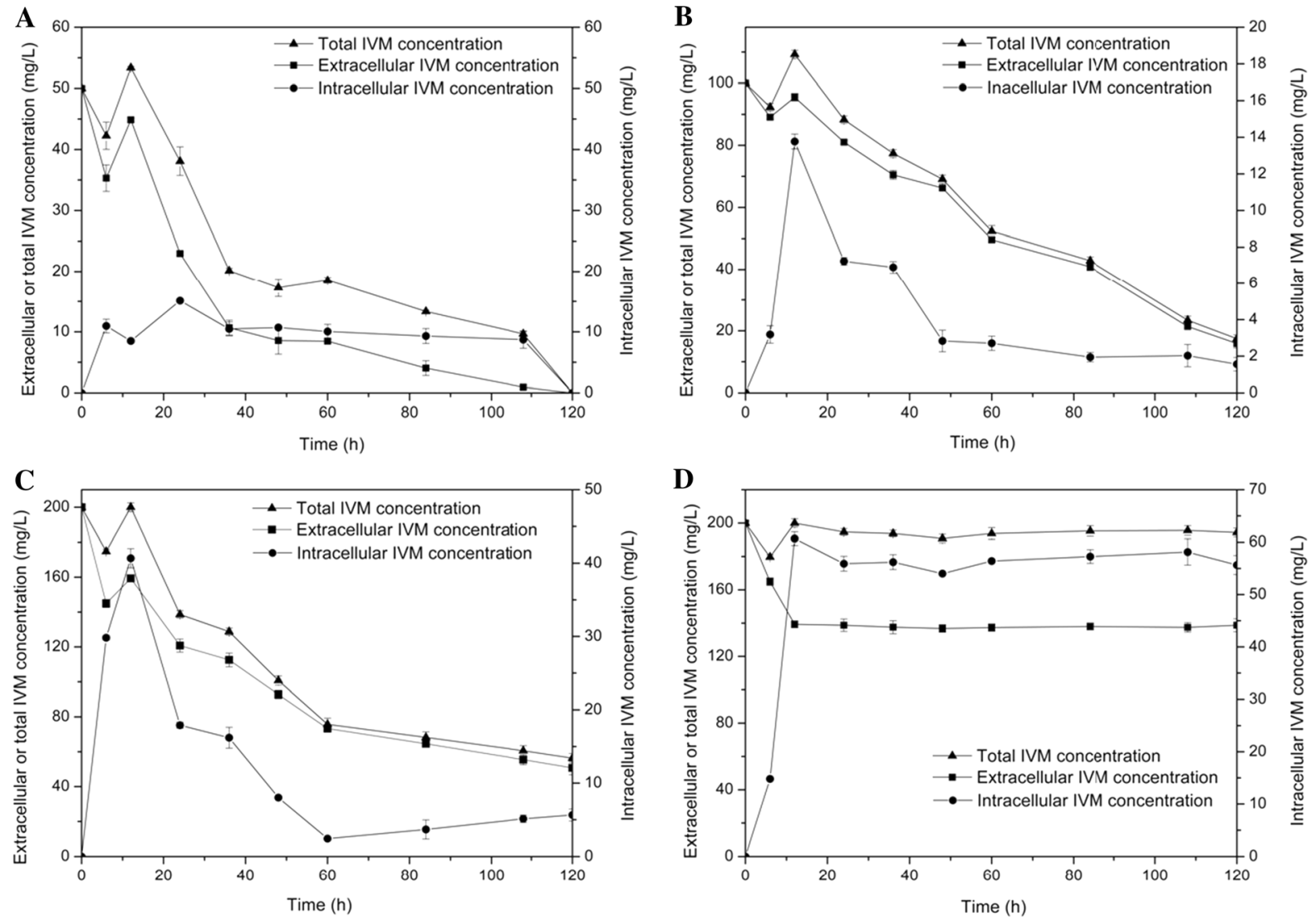

Fig. 8 Profiles of extracellular, intracellular IVM concentration $(v)$, total IVM concentration $(\pi)$ and intracellular IVM content $(\lambda)$ in A. taiwanensis strain ZJB-18,044 growing cells containing $50 \mathrm{mg} / \mathrm{L} \mathrm{IVM} \mathrm{(a),} 100 \mathrm{mg} / \mathrm{L}$ IVM (b), $200 \mathrm{mg} / \mathrm{L} \mathrm{IVM} \mathrm{(c)} \mathrm{and}$

quite rare. These findings provided a primary understanding on microbial degradation of IVM.

IVM can be degraded by strain ZJB-18,044 precultured with or without IVM in LB medium, which indicates that IVM degradation of this strain is an inherent metabolism. Furthermore, IVM could not be degraded by strain ZJB-18,044 on LB with erythromycin, azithromycin or rifampicin, and the mechanism of the inhibition still remains uncovered. However, addition of CCCP can partially recover the IVM degradation ability of ZJB-18,044 inhibited by erythromycin, azithromycin or rifampicin. Since $\mathrm{CCCP}$ is an uncoupler of oxidative phosphorylation, this demonstrated that the efflux pumps on the cytoplasmic membrane might affect the intracellular macrolides concentration (Pages and Amaral 2009). Reports on overexpression of such efflux pumps indicated that a decrease in the concentration of

$200 \mathrm{mg} / \mathrm{L}$ IVM with $8 \mathrm{mg} / \mathrm{L} \mathrm{CCCP} \mathrm{(d).} \mathrm{The} \mathrm{reaction} \mathrm{mixture}$ was incubated at $30^{\circ} \mathrm{C}$ and $150 \mathrm{rpm}$ in $5 \mathrm{~L}$ fermenter for $5 \mathrm{~d}$. Error bars: mean $\pm \mathrm{SD}$ of triplicates

intracellular antibiotics could lead to a decrease in microbial drug sensitivity (Nikaido and Pages 2012). Macrolide efflux pumps systems are also found in Aeromonas sp. including Aeromonas salmonicida (containing efflux pumps to multi-class antibiotics, including macrolide) (Valdes et al. 2015) and Aeromonas hydrophila (with efflux pump to intrinsic multidrug resistance) (Hernould et al. 2008). Genome analysis of Aeromonas taiwanensis revealed the possible presence of efflux pumps such as major facilitator superfamily (MFS), MacB family and resistance-nodulation-division (RND) (Wang et al. 2014). The MFS, MacB and RND efflux pump are closely related to the bacterial drug resistance (Colclough et al. 2020; Greene et al. 2018; Kumar et al. 2020). This may provide the basis for the difference in intracellular and extracellular IVM concentrations. 
The IVM tolerance mechanism of A. taiwanensis strain ZJB-18,044 was described in Fig. 8. The mechanism is similar with the AVM tolerance mechanism of S. maltophilia strain ZJB-14,120 (Wang et al. 2015). According to previous hypothesis, there were significant IVM adsorption and discharge processes in step 1 and step 2. IVM degradation mainly took place in step 3. Compared to the extracellular IVM, the intracellular IVM only accounts for a small portion of total IVM during the degradation (Fig. 8a-c) due to the pump out of excess IVM by efflux pumps. The low IVM concentration inside the cells can avoid the harmful effects of excess IVM. The role of efflux pumps in the regulation of intracellular IVM concentration is further evidenced in Fig. 8c and d.

In summary, the IVM degradation of $A$. taiwanensis strain ZJB-18,044 and its IVM tolerance mechanism were primarily explored in this study. The strain ZJB18,044 can degrade and tolerate IVM, emamectin, doramecyin and spiramycin. Due to its degradation ability, A. taiwanensis strain ZJB-18,044 can be applied in the treatment of water and soils contaminated by IVM, doramecyin, emamectin and spiramycin. Due to the lack of deep insight into the IVM degradation mechanism, low IVM tolerance and long degradation time required ( $5 \mathrm{~d}$ for completely degradation of $50 \mathrm{mg} / \mathrm{L}$ IVM), future work will focus on the elucidation of the IVM degradation pathway, improvement IVM tolerance and degradation efficiency (reduce the time needed) of A. taiwanensis strain ZJB-18,044.

Acknowledgements This work was financially supported by Zhejiang Provincial Natural Science Foundation of China (LY17C010005 and LQ18C010005). We thank Everett J. Bowen, Bachelor of Arts from West Virginia University, for grammar improvement.

\section{Compliance with ethical standards}

Conflict of interest The authors declare no potential conflicts of interest.

\section{References}

Abe T, Bignell D, Higashi T (2000) Termites: evolution, sociality, symbioses, ecology. Springer, Dordrecht

Alekseeva T, Prevot V, Sancelme M, Forano C, Besse-Hoggan P (2011) Enhancing atrazine biodegradation by Pseudomonas sp strain ADP adsorption to layered double hydroxide bionanocomposites. J Hazard Mater 191:126-135. https://doi.org/10.1016/j.jhazmat.2011.04. 050

Ali SW, Li R, Zhou WY, Sun JQ, Guo P, Ma JP, Li SP (2010) Isolation and characterization of an abamectin-degrading Burkholderia cepacia-like GB-01 strain. Biodegradation 21(3):441-452. https://doi.org/10.1007/s10532-009-93147

Aziz MA, Diallo S, Diop IM, Lariviere M, Porta M (1982) Efficacy and tolerance of ivermectin in human onchocerciasis. Lancet 2:171-173. https://doi.org/10.1016/S01406736(82)91026-1

Basyoni MMA, El-Sabaa A-AA (2013) Therapeutic potential of myrrh and ivermectin against experimental Trichinella spiralis infection in mice. Korean J Parasitol 51:297-304. https://doi.org/10.3347/kjp.2013.51.3.297

Batiha GE, Beshbishy AM, Tayebwa DS, Adeyemi OS, Yokoyama N, Igarashi I (2019) Evaluation of the inhibitory effect of ivermectin on the growth of Babesia and Theileria parasites in vitro and in vivo. Trop Med Health 47:42. https://doi.org/10.1186/s41182-019-0171-8

Buonfrate D (2019) Multiple-dose versus single-dose ivermectin for Strongyloides stercoralis infection (Strong Treat 1 to 4): a multicentre, open-label, phase 3, randomised controlled superiority trial. Lancet Infect Dis 19(11):1181-1190. https://doi.org/10.1016/S14733099(19)30289-0

Campbell WC, Fisher MH, Stapley EO, Albers-Schonberg G, Jacob TA (1983) Ivermectin: a potent new antiparasitic agent. Science 221:823-828. https://doi.org/10.1126/ science. 6308762

Caly L, Druce JD, Catton MG, Jans DA, Wagstaff KM (2020) The FDA-approved Drug Ivermectin inhibits the replication of SARS-CoV-2 in vitro. Antiviral Res 3:104787. https://doi.org/10.1016/j.antiviral.2020.104787

Chabala JC, Mrozik H, Tolman RL, Eskola P, Lusi A, Peterson LH, Woods MF, Fisher MH, Campbell WC, Egerton JR, Ostlind DA (1980) Ivermectin, a new broad-spectrum antiparasitic agent. J Med Chem 23:1134-1136. https://doi. org/10.1021/jm00184a014

Chaccour CJ, Kobylinski KC, Bassat Q, Bousema T, Drakeley C, Alonso P, Foy BD (2013) Ivermectin to reduce malaria transmission: a research agenda for a promising new tool for elimination. Malar J 12:153-161. https://doi.org/10. 1186/1475-2875-12-153

Colclough AL, Alav I, Whittle EE, Pugh HL, Darby EM, Legood SW, McNeil HE, Blair JM (2020) RND efflux pumps in Gram-negative bacteria; regulation, structure and role in antibiotic resistance. Future Microbiol 15:143-157. https://doi.org/10.2217/fmb-2019-0235

Costa EM, Araujo EL, Maia AVP, Silva FEL, Bezerra CES, Silva JG (2014) Toxicity of insecticides used in the Brazilian melon crop to the honey bee Apis mellifera under laboratory conditions. Apidologie 45:34-44. https://doi. org/10.1007/s13592-013-0226-5

Crump A (2017) Ivermectin: enigmatic multifaceted 'wonder' drug continues to surprise and exceed expectations. J Antibiotics 70:495-505. https://doi.org/10.1038/ja.2017.11

Davies IM, McHenery JG, Rae GH (1997) Environmental risk from dissolved ivermectin to marine organisms. 
Aquaculture 158:263-275. https://doi.org/10.1016/s00448486(97)00209-3

Davies LM, Gillibrand PA, McHenery JG, Rae GH (1998) Environmental risk of ivermectin to sediment dwelling organisms. Aquaculture 163:29-46. https://doi.org/10. 1016/S0044-8486(98)00211-7

Fischer P, Bamuhiiga J, Buttner DW (1997) Treatment of human Mansonella streptocerca infection with ivermectin. Trop Med Int Health 2:191-199. https://doi.org/10.1046/j. 1365-3156.1997.d01-233.x

Floate KD, Wardhaugh KG, Boxall ABA, Sherratt TN (2005) Fecal residues of veterinary parasiticides: nontarget effects in the pasture environment. Annu Rev Entomol 50:153-179. https://doi.org/10.1146/annurev.ento.50. 071803.130341

Foy BD, Kobylinski KC, da Silva IM, Rasgon JL, Sylla M (2011) Endectocides for malaria control. Trends Parasitol 27:423-428. https://doi.org/10.1016/j.pt.2011.05.007

Gonzalez Canga A, Sahagun Prieto AM, Diez Liebana MJ, Fernandez Martinez N, Sierra Vega M, Garcia Vieitez JJ (2009) The pharmacokinetics and metabolism of ivermectin in domestic animal species. Vet $\mathrm{J}$ 179:25-37. https://doi.org/10.1016/j.tvj1.2007.07.011

Greene NP, Kaplan E, Crow A, Koronakis V (2018) Antibiotic resistance mediated by the MacB ABC transporter family: a structural and functional perspective. Front Microbiol 9:950

Halley BA, Vandenheuvel WJA, Wislocki PG (1993) Environmental-effects of the usage of avermectins in livestock. Vet Parasitol 48:109-125. https://doi.org/10.1016/03044017(93)90149-h

Hao YP (2009) Microbial degradation of ivermectin in pig feces. Dissertation, China Agricultural University

$\mathrm{He} \mathrm{Z}$, Niu C, Lu Z (2014) Individual or synchronous biodegradation of di- $n$-butyl phthalate and phenol by Rhodococcus ruber strain DP-2. J Hazard Mater 273:104-109. https://doi.org/10.1016/j.jhazmat.2014.03. 033

Hernould M, Gagne S, Fournier M, Quentin C, Arpin C (2008) Role of the AheABC efflux pump in Aeromonas hydrophila intrinsic multidrug resistance. Antimicrob Agents Chemother 52:1559-1563. https://doi.org/10.1128/aac. 01052-07

Intuyod K, Hahnvajanawong C, Pinlaor P, Pinlaor S (2019) Anti-parasitic drug ivermectin exhibits potent anticancer activity against gemcitabine-resistant cholangiocarcinoma in vitro. Anticancer Res 39(9):4837-4843. https://doi.org/ 10.21873/anticanres.13669

Ishikawa I, Iwasa M (2020) Toxicological effect of ivermectin on the survival, reproduction, and feeding activity of four species of dung beetles (Coleoptera: Scarabaeidae and Geotrupidae) in Japan. Bull Entomol Res 110(1):106-114. https://doi.org/10.1017/S0007485319000385

Juarez M, Schcolnik-Cabrera A, Dueñas-Gonzalez A (2018) The multitargeted drug ivermectin: from an antiparasitic agent to a repositioned cancer drug. Am J Cancer Res 8(2):317-331

Katharios P, Iliopoulou-Georgudaki J, Antimisiaris S, Kantzaris V, Pavlidis M (2002) Pharmacokinetics of ivermectin in sea bream, Sparus aurata using a direct competitive
ELISA. Fish Physiol Biochem 26:189-195. https://doi.org/ 10.1023/a:1025473904513

Kumar K, Gupta SC, Baidoo SK, Chander Y, Rosen CJ (2005) Antibiotic uptake by plants from soil fertilized with animal manure. J Environ Qual 34:2082-2085. https://doi.org/10. 2134/jeq2005.0026

Kumar M, Jaiswal S, Sodhi KK, Shree P, Singh DK, Agrawal PK, Shukla P (2019) Antibiotics bioremediation: perspectives on its ecotoxicity and resistance. Environ Int 124:448-461. https://doi.org/10.1016/j.envint.2018.12. 065

Kumar S, Lekshmi M, Parvathi A, Ojha M, Wenzel N, Varela MF (2020) Functional and structural roles of the major facilitator superfamily bacterial multidrug efflux pumps. Microorganisms 8(2):266. https://doi.org/10.3390/ microorganisms 8020266

Lane DJ (1991) 16S/23S rRNA sequencing. In: Stackebrandt E, Goodfellow M (eds) Nucleic acid techniques in bacterial systematics. Wiley, London, pp 115-175

Li YH (2010) Screening of avermectin degrading microorganisms and characterization of its degrading mechanism. Dissertation, Yangzhou University

Liu Y, Gao B, Yue Q, Guan Y, Wang Y, Huang L (2012a) Influences of two antibiotic contaminants on the production, release and toxicity of microcystins. Ecotoxicol Environ Saf 77:79-87. https://doi.org/10.1016/j.ecoenv. 2011.10.027

Liu Y, Guan Y, Gao B, Yue Q (2012b) Antioxidant responses and degradation of two antibiotic contaminants in Microcystis aeruginosa. Ecotoxicol Environ Saf 86:23-30. https://doi.org/10.1016/j.ecoenv.2012.09.004

Lumaret J-P, Errouissi F, Floate K, Roembke J, Wardhaugh K (2012) A Review on the toxicity and non-target effects of macrocyclic lactones in terrestrial and aquatic environments. Curr Pharm Biotechnol 13:1004-1060. https://doi. org/10.2174/138920112800399257

Lumaret JP, Errouissi F (2002) Use of anthelmintics in herbivores and evaluation of risks for the non target fauna of pastures. Vet Res 33:547-562. https://doi.org/10.1051/ vetres: 2002038

Masse DI, Saady NMC, Gilbert Y (2014) Potential of biological processes to eliminate antibiotics in livestock manure: an overview. Animals 4:146-163. https://doi.org/10.3390/ ani4020146

Miró-Canturri A, Ayerbe-Algaba R, Smani Y (2019) Drug repurposing for the treatment of bacterial and fungal infections. Front Microbiol 10:41. https://doi.org/10.3389/ fmicb.2019.00041

Mladineo I, Marsic-Lucic J, Buzancic M (2006) Toxicity and gross pathology of ivermectin bath treatment in sea bream Sparus aurata, L. Ecotoxicol Environ Saf 63:438-442. https://doi.org/10.1016/j.ecoenv.2005.02.015

Mo JC, He HY, Song XG, Chen CR, Cheng J (2005) Toxicity of ivermectin to Reticulitermes flaviceps (Isoptera: Rhinotermitidae). Sociobiology 46:603-613

Nagano K, Nikaido H (2009) Kinetic behavior of the major multidrug efflux pump AcrB of Escherichia coli. Proc Natl Acad Sci USA 106:5854-5858. https://doi.org/10.1073/ pnas.0901695106

Nikaido H, Pages J-M (2012) Broad-specificity efflux pumps and their role in multidrug resistance of Gram-negative 
bacteria. FEMS Microbiol Rev 36:340-363. https://doi. org/10.1111/j.1574-6976.2011.00290.x

Olsen RW, Snowman AM (1985) Avermectin B1a modulation of gamma-aminobutyric acid/benzodiazepine receptor binding in mammalian brain. J Neurochem 44:1074-1082. https://doi.org/10.1111/j.1471-4159.1985.tb08727.x

Omura S (2008) Ivermectin: 25 years and still going strong. Int J Antimicrob Agents 31:91-98. https://doi.org/10.1016/j. ijantimicag.2007.08.023

Omura S, Crump A (2014) Ivermectin: panacea for resourcepoor communities? Trends Parasitol 30:445-455. https:// doi.org/10.1016/j.pt.2014.07.005

Pages JM, Amaral L (2009) Mechanisms of drug efflux and strategies to combat them: challenging the efflux pump of Gram-negative bacteria. Bba-Proteins Proteom 1794: 826-833. https://doi.org/10.1016/j.bbapap.2008.12.011

Panayotova-Pencheva MS (2016) Experience in the ivermectin treatment of internal parasites in zoo and captive wild animals: a review. Zool Garten 85:280-308. https://doi. org/10.1016/j.zoolgart.2016.04.001

Pande V, Pandey SC, Sati D, Pande V, Samant M (2020) Bioremediation: an emerging effective approach towards environment restoration. Environ Sustain 3:91-103. https://doi.org/10.1007/s42398-020-00099-w

Poul JM (1988) Effects of perinatal ivermectin exposure on behavioral development of rats. Neurotoxicol Teratol 10:267-272. https://doi.org/10.1016/0892-0362(88)90027-x

Sanderson H, Laird B, Pope L, Brain R, Wilson C, Johnson D, Bryning G, Peregrine AS, Boxall A, Solomon K (2007) Assessment of the environmental fate and effects of ivermectin in aquatic mesocosms. Aquat Toxicol 85:229-240. https://doi.org/10.1016/j.aquatox.2007.08.011

Sangare AK, Rolain JM, Gaudart J, Weber P, Raoult D (2016) Synergistic activity of antibiotics combined with ivermectin to kill body lice. Int J Antimicrob Agents 47: 217-223. https://doi.org/10.1016/j.ijantimicag.2016.01.001

Sutherland IH, Campbell WC (1990) Development, pharmacokinetics and mode of action of ivermectin. Acta Leiden 59:161-168

Thompson JD, Higgins DG, Gibson TJ (1994) Clustal-W Improving the sensitivity of progressive multiple sequence alignment through sequence weighting, position-specific gap penalties and weight matrix choice. Nucleic Acids Res 22:4673-4680. https://doi.org/10.1093/nar/22.22.4673

Uhlir J, Volf P (1992) Ivermectin-Its effect on the immune system of rabbits and rats infested with ectoparasites. Vet
Immunol Immunopathol 34:325-336. https://doi.org/10. 1016/0165-2427(92)90173-n

Valdes N, Espinoza C, Sanhueza L, Gonzalez A, Corsini G, Tello M (2015) Draft genome sequence of the Chilean isolate Aeromonas salmonicida strain CBA100. FEMS Microbiol Lett 362:1-4. https://doi.org/10.1093/femsle/ fnu062

Verdú JC, Cortez V, Ortiz AJ, González-Rodríguez E, MartinezPinna J, Lumaret JP, Lobo JM, Numa C, Sánchez-Piñero F (2015) Low doses of ivermectin cause sensory and locomotor disorders in dung beetles. Sci Rep 5:13912. https:// doi.org/10.1038/srep13912

Wang D, Han B, Li S, Cao Y, Du X, Lu T (2019) Environmental fate of the anti-parasitic ivermectin in an aquatic microecological system after a single oral administration. Peer J 7:e7805. https://doi.org/10.7717/peerj.7805

Wang HC, Ko WC, Shu HYu, Chen PL, Wang YC, Wu CJ (2014) Genome sequence of Aeromonas taiwanensis LMG 24683T, a clinical wound isolate from Taiwan. Genome Announc 2(3):e00579-e00514. https://doi.org/10.1128/ genomeA.00579-14

Wang YS, Zheng XC, Hu QW, Zheng YG (2015) Degradation of abamectin by newly isolated Stenotrophomonas maltophilia ZJB-14120 and characterization of its abamectintolerance mechanism. Res Microbiol 166:408-418. https:// doi.org/10.1016/j.resmic.2015.04.002

Wu H, Jiang M, Peng ZX, He L (2012) Research on the degradation of ivermectin and its acute toxicity to seven aquatic organisms. Acta Hydrobiol Sin 36(5):965-970. https://doi.org/10.3724/SP.J.1035.2012.00965

Yates DM, Portillo V, Wolstenholme AJ (2003) The avermectin receptors of Haemonchus contortus and Caenorhabditis elegans. Int J Parasitol 33:1183-1193. https://doi.org/10. 1016/s0020-7519(03)00172-3

Yang SNY, Atkinson SC, Wang C, Lee A, Bogoyevitch MA, Borg NA, Jans DA (2020) The broad spectrum antiviral ivermectin targets the host nuclear transport importin $\alpha / \beta 1$ heterodimer. Antiviral Res 2:104760. https://doi.org/10. 1016/j.antiviral.2020.104760

Publisher's Note Springer Nature remains neutral with regard to jurisdictional claims in published maps and institutional affiliations. 